\title{
Interreligious Learning, Ricoeur, and the Problem of Testimonial and Hermeneutical Injustice
}

\author{
Marianne Moyaert
}

Vrije Universiteit Amsterdam

\begin{abstract}
Ricoeur's philosophy of religion as well as his suggestion that we may consider interreligious dialogue as a specific form of linguistic hospitality has inspired many to think through the challenges of interfaith learning in a post-secular age. I am one of those scholars who have found Ricoeur a particularly helpful conversation partner as I sought to create a nonviolent and transformative space of encounter in my interreligious classroom. In this article, I elaborate on how my lived experiences as an interreligious educator have made me wonder if Ricoeur's philosophy of religion and his plea for interreligious hospitality are not actually limiting the critical potential of interreligious education. Ricoeur's interreligious hermeneutics strongly resonates with a modern (Protestant) understanding of religion and its implicit, normative distinction between good (mature) and bad (immature) religiosity, which to this day belongs to the sociopolitical imagination of the majority in most Western European countries (this is certainly true for the Netherlands). It has been my pedagogical experience that this distinction between good and bad religion contributes to and reinforces testimonial and hermeneutical injustice in my classroom, which results in the marginalization of some of my students, especially those whose religious practice does not fit the understanding of what religion ought to be.
\end{abstract}

\section{Keywords}

critical hermeneutics; interreligious dialogue; interfaith education; Miranda Fricker; religious diversity

Interreligious educators often draw upon philosophers of religion who distinguish between good and bad religion/mature and immature faith. If good religion clusters with terms such as 'authenticity, spirituality, interiority, faith, and reason, but also peacefulness and open-mindedness', bad religion is associated with 'formalism, dogmatism, ritualism, materialism, and irrationality as well as violence and closed-mindedness' (Beck 2014). In this

\footnotetext{
* Marianne Moyaert, Faculty of Religion and Theology, Vrije Universiteit Amsterdam, De Boelelaan 1105, 1081 HV Amsterdam, the Netherlands; m.moyaert@vu.nl.
} 
article and based on my own experiences as an interreligious educator, I focus my attention to the way this seemingly 'self-evident' distinction, a distinction which one could add is also deeply ingrained in the sociopolitical imagination of most Western liberal nation-states (McCutcheon 2005, 22008), may actually limit the process of interreligious learning.

To clarify the distinction between good and bad religion, I turn to the French philosopher Paul Ricoeur, one of the great minds of the twentieth century. Although Ricoeur only sporadically raised the issue of interreligious dialogue, his philosophy of religion as well as his suggestion that we may consider interreligious dialogue as a specific form of linguistic hospitality has inspired many to think through the challenges of interfaith learning (Kearney 2011; Matern 2008; Jervolino 2006; Garcia 2008). Ricoeur is furthermore interesting, because his philosophy of religion epitomizes the distinction between good and bad religion. In response to the reality of religious violence, he projects a post-religious, mature faith, which opens up the horizon for transformative interreligious encounter and which is clearly distinguished from immature, dogmatic, and exclusivistic faith. This is precisely what many interreligious scholars, myself included, find so appealing about his work (Moyaert 2014).

After summarizing the main aspects of Ricoeur's philosophy of religion, I will showcase how Ricoeur's philosophy of religion ends up dividing my classroom into 'liberal, mature' students, who seem to believe that they embody the virtue of openness and 'conservative, immature' students, who according to the first, still need to cover a considerable distance to become competent in dialogue. The latter's perspective and what they have to contribute to the conversation are simply not taken seriously. I continue by arguing that these classroom situations are textbook examples of what critical epistemologist Miranda Fricker calls situations of testimonial and hermeneutical injustice.

In the final part of my article, I seek to critique the self-evident status of the normative distinction between good and bad religion. To that end, I will show how the category of religion itself is the product of a particular historicocultural context. As any historico-culturally determined category it is marked by various contingent ideological assumptions that ought to be submitted to careful examination. When interreligious educators refrain from such critical examination, they may end with interfaith programs that enhance the domestication of religion. 


\section{Ricoeur's Philosophy of Religion}

Ricoeur was deeply concerned about the resurgence of religiously inspired violence and the fact that people to this day continue to kill "in the name of God." Long before 9/11, which according to some symbolically marks the 'return of religion' (Fitzgerald 2011), Ricoeur advised that it would be unwise to minimalize the reality of religious violence. To his mind, we must recognize and confront the fact that there is an intimate relation between religion and violence. Religious violence springs from the all-too human inclination to contain that what may not be contained, to grasp that what may not be grasped, and to seize that what may not be seized. The desire for containment (and control) is an expression of immature faith and results in bad religion, to let go of this desire is a sign of mature faith and gives way to good religion. If bad religion leads to violence, good religion leads to peaceful coexistence and opens up the possibility of interreligious hospitality.

According to Ricoeur, "every religion claims to give a human answer to a questioning that comes from above, from a higher level than the human" (Changeux \& Ricoeur 2002, 269). Inspired by Schelling, Ricoeur calls this transcendence the groundless ground, the Grund that is Abgrund, the foundation without foundation. This "conceptualization" of a foundation without foundation brings into focus the fact that no one can lay hold of this groundless ground. Ricoeur elsewhere calls it "un point de fuite" (vanishing point); it is a limit idea for understanding the illimitable condition of religious experience (Ricoeur 1977, 42). It can never be captured (Staudigl 2016, 782). In distancing itself from the tradition of ontotheology, this conceptualization of a groundless ground does not function as the first basis on which one can build a solid house; on the contrary, this groundless ground eludes any attempt to master it. The mature faith of the modern man presumes a letting go of the desire to control the groundless ground. Deep down, the authentic religious attitude is a vulnerable outlook, responding to what is beyond human mastery. Here, vulnerability refers to the fundamental human ability to be receptive to "something" completely "Other" and realizing that one may never fully grasp it.

Ricoeur speaks about this groundless ground as the source of life, which is marked by superabundance as an overflow of meaning and an excess of love; a gift of life. This source of life stands in a dialectic relation with the finite human capacity of reception, adaptation, and appropriation. The result is a

1 The following paragraph is a shortened and revised version of chapter 2 of Moyaert (2014). 
disproportion between what is infinite and finite, between what is excessive and limited (Ricoeur 2010, 35).

Confronted with an overflow from above, as it were, [the capable man] tries to accommodate this excess by closing up the sides-laterally, horizontally. This amounts to trying to contain-in both senses of the word-what exceeds all containing. The lateral closure offsets the vertical opening (Changeaux \& Ricoeur 2002, 269).

Because of the infinite source of life fragments according to its different receptions, religion can never exist in the singular. As a consequence, the religious landscape is irrevocably splintered. Human beings, however, find this reality difficult to accept: all want to capture the source; none can live with the fact that there is something that eludes them, that they cannot control, and that escapes them. For Ricoeur, the exclusion of others is the reverse side of the domestication of the groundless ground. To put it in "ethical terms," believers who are unable to deal with the "otherness" of the source of lifeits excess, mystery, and transcendence-will in all likelihood turn out to be unable to deal with the otherness of religious other (Ricoeur 1999, 10).

All the other historical communities who lay claim to the same transcendence, but in terms of a different confession, appear as rivals in the struggle for appropriation of Being, the absolute Other, which is treated as a selfsame object to be possessed to the exclusion of the other possessors. So then the other communities are the rivals for this object of desire-fear, rivals in the reductively possessive reception of transcendence that is constituted by the very foundational instruction. Here is the source of exclusion of the other communities considered to be impious, heretical, impure, etc....(Ricoeur 1999, 10).

As Ricoeur sees it, there is a clear connection between preserving the transcendence of the groundless ground and making room for the otherness of the other: the inability to accept the otherness of the source of all life goes hand in hand with an inability to deal with the otherness of the religious other.

To break through the spiral of ethnocentric tendencies and assist in decreasing, or at least opening up discussions concerning interreligious conflicts, Ricoeur reserves an important place for the so-called masters of suspicion: Freud, Marx, and Nietzsche. They have taught us to critically relate to our traditions and probe into the deeper, often unconscious, and problematic dynamics that motivate our traditional cultural attachments that can be brought to light only by adopting a hermeneutical attitude of suspicion and scrutiny. Their atheism offers a critical instrument of demystification, bringing to light the deadly nature of the ontotheological god. In Ricoeur's understanding, atheism does not come to destroy religion as such; rather, it points in the direction of what 
he calls a post-religious faith (Ricoeur 1974, 440). In this sense, the critique of atheism really does have liberating potential.

Next, the challenge is to cultivate a spirit of 'interreligious hospitality', "where the pleasure of dwelling in the other's [religious] language is balanced by the pleasure of receiving the foreign word at home, in one's own welcoming house" (Ricoeur 2006, 10). Extending hospitality to the religious other is about learning to take responsibility, in imagination and sympathy, for the perspective of the other, and accepting this responsibility expresses a willingness to be interrupted, challenged, and being pulled away from what is known and familiar to what is unknown and strange. The potential outcome of such a process is a reconfiguration of one's own self-understanding as well as that of the other. What is more, in the encounter with the religious other, one may also rediscover the deep religious truth that no tradition can ever absorb the illimited nor can it deplete its meaning. Thus, interreligious hospitality could testify to the greatness of the groundless ground and to the fact that the divine has many names, which may even contradict one another.

The condition for this ethical posture of interreligious hospitality is a postreligious understanding of faith that accepts the enduring tension between the finite and the infinite, between what is relative and absolute, and between the plural and the singular. On the one hand, it is understood that what is infinite is a limit idea that can never be grasped in absolute terms. Here, transcendence is truly accepted; the radical otherness of the illimited is affirmed. On the other hand, this post-religious faith also recognizes that one can only relate to the illimited through mediations, i.e., texts, symbols, and even institutions.

Although he did not develop a full-fledged hermeneutics of interreligious hospitality, it is reasonable to expect that a Ricoeurian interreligious hermeneutics would primarily focus on reading and interpreting symbols and especially (sacred) texts. After all, Ricoeur stated that "whatever ultimately may be the nature of the so-called religious experience, it comes to language, it is articulated in a language, and the most appropriate place to interpret it on its own terms is to inquire into its linguistic expression" (Ricoeur 1995, 35). Texts, rather than religious objects and ritual practices, which he associated the lure of "immediacy, effusiveness, intuitionism," are for him the most obvious place to start when one tries to understand another religion.

\section{The Reception of Ricoeur's Philosophy of Religion in My Multireligious Classroom}

I work at the Vrije Universiteit Amsterdam (the Netherlands) at the Faculty of Religion and Theology. Recognizing that our society is undergoing processes of 
not only secularization but also pluralization, this faculty, while respecting its roots in reformed tradition, has become a center where not only Mennonites, Humanists, Baptists, and Orthodox Christians receive their formation but also Hindus and Buddhists, as well as Muslims. Here, students are being trained to become theologians, pastors, imams or Buddhist and Hindu spiritual care givers and we form them to take up leadership positions in their respective religious communities. However, we also believe that religious literacy ought to go hand in hand with interreligious literacy. According to the vision of my faculty, our secularized and pluralized world needs religious leaders who have the flexibility to move between different worlds and translate their convictions in a meaningful way to those who believe and practice differently. It is my pedagogical task to form these students in such a way that they may become religious leaders who are also interreligiously literate.

To make this more concrete, I have opted for an interreligious practice known as scriptural reasoning, which aims at building interreligious communion through a praxis of reading and studying the sacred scriptural texts together (Moyaert 2017a; 2017b). In quite a Ricoeurian way, scriptural reasoning presents itself as a praxis of mutual hospitality, in which each "is host to the others and guest to the others as each welcomes the other two to their 'home' scripture and its traditions of interpretation" (Ford 2006, 349). Over a time period of approximately six weeks, they will meet in groups of about 9-12 students, where they will read, interpret, and comment small scriptural portions (e.g., from the Qur'an and Hadith as well as from the Bible), which deal with a comparable theme, e.g., forgiveness and reconciliation, family values, prophecy. Students engage in a comparative close reading of these scriptural portions and pore over possible interpretations, and ask what these texts may mean to them today (Moyaert 2017, 3-26).

Some classroom situations have incited me to reconsider Ricoeur's interreligious hermeneutics and whether it really provides the best possible framework to enable a shift from exclusion and violence to inclusion and peace. On the one hand, I cannot but notice that Ricoeur's philosophy of religion, with all its sophistication, actually meshes with an understanding of religion that is widely accepted in a more rudimentary form throughout popular Dutch protestanticized culture, and this is especially the case for his normative distinction between good (mature) and bad (immature) religiosity. In my classroom, Ricoeur's philosophy of religion and his vision of interreligious hospitality are welcomed especially among those students who self-identify as liberal Protestant and post-Christian or those who call themselves spiritual but not religious as well as students (each year I have 2 or 3) who claim to be 
multiple religious belongers. I observe, how Ricoeur's philosophy of religion actually reaffirms that they are right, read open, inclusive, dialogical, and nonviolent. Ricoeur's philosophy of religion, to a large extent, coincides with their own understanding of interreligious openness, their allergy vis-à-vis any kind of dogmatism, their search for wisdom, their sensitivity for the religious paradox, i.e., the dialectic of disproportion between the ineffable nature of the 'source of life', and the historically culturally contingent nature of human finite responses to this source of life. They agree that Ricoeur's philosophy of religion points them in the direction of mature faith - a post-religious faith - that offers a perspective beyond religious violence and paves the way for dialogical openness.

The situation is completely different for my reformed Protestant students, the Eastern Orthodox Christians, Roman and Old Catholics, and Muslims (mostly Sunni), and also some of my Buddhist and Hindu students. They do not recognize themselves in Ricoeur's philosophical project, which does not do justice to the particularity of their faith and also does not quite capture the specific nature of their religious practice. Within this Ricoeurian framework, furthermore, they find themselves being associated with an immature faith, absolutism, naïve religiosity, and sometimes even with the inability to dialogue and it is not uncommon that when they seek to convey their concerns about the way interreligious learning is being hermeneutically and philosophically framed (by me and with the support of my more liberal students) that their 'testimony' falls on deaf ears.

Let me make this more concrete in reference to some classroom situations that have occurred during the past couple of years:

- During one of my scriptural reasoning sessions, a Muslim student objected to his colleagues touching and handling the Qur'an as if it was any ordinary book. She explained that the Quran is the word of God and therefore a sacred book. She tried to elaborate on why one may not touch the Qur'an without having performed Wudu (ritual washing). Her Muslim colleagues agreed and tried to communicate that they had no problem with their colleagues reading the Qur'an from their iPad, but that it would be offensive if they would touch the Qur'an as if it were a mere study object. Their concern was met with disbelief. Especially, my liberal Protestant students murmured this is precisely what is wrong with Islam - the fact that this religion has not gone through the critique of the Enlightenment and fiercely holds on to fundamentalist attachments to the matter of the text without understanding that what we should focus on is the meaning of the text and what it reveals about the divine. More than ever, they were 
convinced that Islam needs to confront itself with the masters of suspicion like Christianity has had to do more than a century ago.

- When organizing scriptural reasoning sessions involving not only Christian and Muslim students but also Buddhists, the latter, while enjoying reading sacred scriptures across traditions, expressed that they did not feel quite comfortable with the textual focus of my scriptural reasoning sessions. They point out that it is a misconstrual to depict 'Buddhism' as scriptural tradition. In their lived experience, small and great rituals are far more important and the scriptures are actually only read and studied by the elite. If one were to understand their 'religion', one should rather participate in its rituals. My Protestant Christian students raise their eyebrows, "but how can one understand the rituals without their accompanying books?" Surely, the preliminary access to deeper religious understanding is via texts.

- After visiting a Hindu Temple, some of my Protestant students had difficulties concealing their astonishment and bafflement over the seriousness with which their Hindu colleagues engaged in the puja rituals. My Hindu students explained two key elements of the ritual: Darśana and prasada. The first points to the idea that when entering the Temple, one sees and is being seen by the Mürti. Darśana may be rendered as sacred seeing, and it springs from the consciousness of being seen by God in whose presence one stands. God's eyes are upon the devout Hindu: he/she sees and is seen. A second element of Hindu worship is Prasāda. The Hindu worshiper offers something, usually edible to the Mūrti. After worship, a portion is returned to the worshiper as a priceless gift from God. Key to the ritual is the significance of the Mūrti as an embodiment of God. I remember my Protestant students asking if they (their Hindu students) really believed these statues represented God, if they really believed the food they offered was returned to them as a sacred gift (they were barely able to constrain themselves from saying, 'you do know these are just statues'....)

All three interfaith situations created misunderstanding and bridging the hermeneutical gap between the different parties turned out to be quite difficult. What is more, especially those students that are sometimes called 'conservative rather than liberal' were pushed in the defense, while my liberal students found themselves on the right side of the fault line; Ricoeur's philosophy of religion reaffirmed their sense of embodying authentic religiosity.

\section{Testimonial and Hermeneutical Injustice}

Inspired by the work of critical epistemologist Miranda Fricker, I have come to understand the above-described classroom situations as examples 
of hermeneutical and testimonial injustice. In her book Epistemic Injustice: Power and the Ethics of Knowing, Fricker explains that testimonial injustice "happens whenever prejudice on the part of a hearer causes them to attribute a deflated level of credibility to a speaker's word" (Fricker 2007, 1). Testimonial injustice is about not accrediting the appropriate credibility to someone's testimonial activity, not because the speaker has nothing meaningful to say or contribute to the conversation, but rather because she is simply not recognized as a credible source of knowledge. Testimonial injustice, Fricker explains, harms someone in her capacity as knower and usually it takes root in pervasive negative prejudice. When prejudice gets a hold on a hearer, it affects his judgment of a speaker, leading him to unduly deflate the speaker's level of credibility.

In my classroom, this plays out as follows. Whenever students (whatever religion - Christian, Muslim, Buddhist - they practice) invoke what is perceived by my liberal students as too strong an attachment to the material (palpable, visible), ritual (rule-governed and formalized behavior, symbolic objects, ritualized roles), and spatial dimensions of their religion, their credibility status is lowered. They are taken less seriously by their colleagues and what they say to explain their behavior falls on deaf ears. I have come to understand that my liberal students associate some of their colleagues' religious practices with immature, premodern, and precritical faith. Attachment to the matter of the book (the Qur'an) or the veneration of the Mūrtis is regarded as childish, certainly compared to their own postcritical textualized and hermeneutical understanding of Christian religion. The fact that the credibility status of some students is lowered leads their hearers (more liberal students) to suspend their hermeneutical openness. It is not uncommon that students who experience how their voice is being silenced, likewise suspend their involvement in the conversation.

Miranda Fricker points out that testimonial injustice is inextricably related to what she calls hermeneutical injustice, i.e., "the injustice of having some significant area of one's social experience obscured from collective understanding owing to hermeneutical marginalization" (Fricker 2007, 155). Hermeneutical injustice occurs especially when an individual/social group has unequal opportunity to contribute to what pertains to the widely shared concepts of the sociopolitical imaginary, thereby at once constituting her/ them as a less than full partner in the social interaction. There is a mismatch between their experiences (and the concepts they use to make sense of these experiences) and the available concepts and ideas that belong to the sociopolitical imaginary and this conceptual mismatch or hermeneutical gap, 
as it is sometimes also called, hinders communication, and limits mutual understanding and transformation.

Although hermeneutical and testimonial injustice are two distinct forms of epistemic injustice, both are interrelated and reinforce each other. On the one hand, hermeneutical injustice is perpetuated by negative identity prejudices, which lead hearer's to negatively judge the credibility of any speaker trying to communicate a significant social experience that does not fit in with the widely shared concepts of the powerful social group in a society. If one does not understand someone or finds that she is simply not making sense, but ascribes her $a$ high amount of credibility, one will by all likelihood push through and listen carefully and generously, until one reaches understanding. No such efforts will be made if a negative judgment of the credibility status of the speaker is in place. On the other hand, Fricker has a point when she declares that hermeneutical injustice usually precedes testimonial injustice: "Lacking the conceptual and interpretive tools you need to [render intelligible] some significant patch of your social experience is prior the difficulties of getting your word received without prejudice once you have put your thoughts together in intelligible form" (Dieleman 2012).

It is my hypothesis that (1) the Dutch sociopolitical imagination (and I assume this goes for many Western societies) has been penetrated by a very specific understanding of what religion (ideally speaking) should be (i.e., good religion) and what it should not be (bad religion). This understanding has acquired the status of being self-evident. (2) Interreligious educators, myself included, are drawn to Ricoeur's philosophy of religion precisely because it resonates with this distinction between good and bad religion. (3) When I build on Ricoeur to frame my interreligious education, I actually reinforce my liberal Protestant students' sense that their interpretation of religion is the way toward mature faith, openness, and dialogical reciprocity while I simultaneously communicate to my other students that their interpretation of religion is immature. (4) The latter's credibility status is lowered, as a consequence of which they are unable to communicate the significance and particularity of their religious practice to their liberal students. The process of learning comes to a full stop.

The more fundamental problem is that category of religion (together with the normative distinction between good and bad religion) functions as a selfevident, ahistorical, and decontextualized category which claims a universal scope. That this category is itself the product of a particular historico-cultural context goes unnoticed (Nonbri 2013, 1). As a consequence, the underlying ideological assumptions attached to this category are never called into 
question and mature faith, as distinguished from immature faith, receives the status of a learning target (e.g., Pollefeyt \& Bouwens, 2014).

In the final part of this article, I make some critical remarks about the category of religion. I especially bring to the surface that this term has a history and that the distinction between good and bad religion is not innocent (King 1999, 35). Although it is simply not possible to develop a complete and exhaustive history of the notion of religion in the scope of this article, I will seek to highlight how the normative distinction between mature and immature faith has crystalized in modern history and needs to be understood against the background of conflicts between Catholics and Protestants in the $16^{\text {th }}$ to $17^{\text {th }}$ centuries. Doing so will also enable me to argue how Ricoeur proves himself to be a heir of a modern/Protestant understanding of religion, which has become dominant in both liberal democratic societies and in academia.

\section{Thinking 'Religion' in the Context of European Modernity}

Scholars such as Talal Asad, Richard, King, Robert Orsi, Tomoko Masuzawa, and Timothy Fitzgerald and others have undertaken a critical study of the notion of religion, tracing it back to the "intellectual histories of European modernities" (Blackburn 2012, 154). Their work enables us to understand how the distinction between immature, naïve, childish, and potentially violent religious expressions and mature, critical, wise, and peaceful religious expressions is part and parcel of the history of religion and the religious project to differentiate between people and their cultures. There is not room here in this article to recapitulate in detail the complex history of the generic notion of religion and how it is entangled in European Christianity understood as an expansionary colonial project (Daggers 2013); this would simply take up too much time. However, here, bearing in mind the specific subject of this article, i.e., the distinction between good and bad religion and how it may add to unequal power relations in religiously mixed classrooms, I try to contribute in broadest outlines to the historiographical clarification of this normative distinction.

As several scholars have pointed out, key to understand this distinction is the history of deep disagreement between Protestants and Catholics, resulting in division, persecution, and even religious war. The notion of 'good' religion that emerged from this conflict served the purpose of "transcending violent conflicts" that had characterized European Christianity for such a long time (Daggers 2013, 22). To further elaborate on this, I turn to the work of scholar of religion Robert Orsi, who has a specific interest in the historiography of the notion of religion, the ideological assumptions that underpin it and how it 
continues to affect the way contemporary religious and interreligious scholars try to make sense of religious phenomena and interfaith relations.

In his publication History and Presence, Orsi argues that the collective memory of the conflict between Protestants and Catholics is deeply encoded in the DNA of our modern understanding of religion. While risking the accusation of caricaturing religious history, he interprets this conflict in terms of presence vs. absence; a conflict that reached its climax in the debate over the nature of the divine body in the host. If Catholics held on to the age-old idea of the presentia realis or sacramental presence, which points to the power of symbols to make present what is sacred, protestants saw the significance of table communion mainly in its commemorative dimension (in memory of). Thus, Orsi states:

Among non-Catholics, [real presence] meant the disgusting idea that Jesus's actual body was there to be crunched on in the Host, his blood guzzled from the chalice, and among Catholics, it meat the reality of the Catholic supernatural as opposed to the empty simulacrum of the Protestant holy. Catholics became the people of real presence par excellence, in the Eucharistic theology and in their devotional practices,...practices that included eating holy cards, rubbing holy dirt on the place where the body of a loved one hurts, having the dead arrive back home, and soon. Kissing the finger-bone of a dead human (more likely a goat's bone) - how ridiculous (Orsi 2016, 9).

The debate about the religious meaning of the Eucharist/table communion actually revolves around two different understandings of religion: one gravitating toward expression and the other toward presence. In the first case, religious symbols point beyond themselves to what is transcendent, which may not be captured. In the second case, the idea is that the sacred moves in what is tangible and visible and hence the importance of concrete religious aspects (DeDijn 1999, 373). From this perspective, it becomes understandable why bodily contact with certain symbols is so important-eating the host, kissing a statue, touching a relic, etc. These religious acts are seen by the first as expressions of superstition at best and idolatry at worst, while the latter regard it as part and parcel of their devotional practice. Orsi continues by saying that what began as a dispute between Christians about divergent conceptions of presence, not only "became a point of absolute division between Catholics and Protestants" but also turned into "one of the normative categories of modernity" and the way religions would be conceptualized and categorized (Orsi 2016, 9).

Over time, the conflicts between Protestants and Catholics turned violent and sadly climaxed into violence. To this day, it is assumed that religion has been 
"the main cause of the Wars of Religion in the seventeenth century Europe, as a result of which reasonable men (women had little to do with it, apparently) had to expel religion from politics and establish the non-religious state as the essentially rational and peace-living arbiter of violent religious disputes" (Fitgzerald 2011, 79). From that time period, we retain three key ides that have become part of the sociopolitical imagination of most liberal nation-states. First, that religion is an ambiguous phenomenon that cannot be left alone, because at heart it (cf., Ricoeur) may turn violent. Therefore, it needs to be closely monitored (Fitzgerald 2011, 78). From this perspective, secularization (separation between church and state) is required to ensure that religious conflict does not turn violent. Second key idea, which is interrelated with the first but further complexifies it, is that religion has two faces: a benevolent and a malevolent one (Beck 2014). Benevolent religion is "essentially peaceloving, non-violent, non-political, non-profit-making, concerned with the inner spiritual life and the other world....[Here] religion is a matter of personal faith and piety, essentially separated from the non-religions secular states, ...." Malevolent religion is "barbarous, violent and irrational, causing conflict and mayhem wherever it raises its ugly head" (Fitzgerald 2011, 78). The third idea is that essentially (i.e., according to its true nature) religion is private, personal, pious, and interiorized, religion turned violent is basically a perversion of true religion. To restore religion to its true nature, it has to be turned inward, become pious and somewhat detached from ostentation.

Reconnecting with Orsi's earlier reflections, we see how benevolent religion (i.e., true religion) becomes intertwined with the Protestant model of absence, according to which religious symbols derive their significance from the way they point beyond themselves and help orient the believer to what is of ultimate concern. The symbols themselves, however, are only of penultimate importance. That distinction is crucial. True religion does not cling to the material (visible, palpable, smellable, ...), ritual, or legal dimensions of religion; it accepts external criticism and strives after detachment and accepts that the source of life may not be captured. Good religion has no need of frills or show and views all those externalities as historico-culturally determined and thus relative. It knows that it cannot lose itself in this kind of detail but must focus on what is ultimately important; it cannot be captured in human images. The emphasis is put on "on interiority, personal faith and sincerity of the beliefs ends with an idea of religiosity as a completely existential experience..." (Rosatti 2009, 27). Authentic religiosity or mature faith thus detaches people from their attachment to material and ritual forms and liberates them from the risks of empty formalism and inauthenticity (Van Herck 2007, 138). 
Bad or malevolent religion, on the other hand, is visible, palpable, smellable - it is not shy but draws all attention on itself. It is anything but modest and focuses too much on outward show. Bad religion is the result of a fallacy: it confuses what is ultimate and penultimate, thereby at once reducing the first to the latter. The end result is idolatry, i.e., seizing the source that may not be seized. This fallacy may spring from a human desire of control or from an immature and childish faith that has not yet reached the stage of rational and critical faith. In any case, believers and their communities who are too attached to the material and ritual dimensions of religion prove to be immature, premodern, and irrational - theirs is unenlightened superstitious religion. This is also where the roots of religious violence lie, i.e., in religion that revolves around the notion of presence. If all religions conform to the model of mature religion, there will be no more violence.

Orsi suggests that one of the reasons why "sacred presence was so fiercely stigmatized was because of its conscious and unconscious association with Catholicism" (Orsi 2016, 33). He adds that this stigma of religious practices that revolve around sacred presence rather than absence was later exported during missionaries activities in non-European areas. He points out how "charges of religious cannibalism, idolatry, and gross materiality traveled back and forth across the seas, with traders, soldiers, and missionaries" (Orsi 2016, 33). Over time, this fault line between Protestants and Catholics would also "run through the nascent field of the academic study of religion," which basically took over this normative framework and set up binary structures between 'us' and 'them. ${ }^{2}$ Richard Fardon likewise states:

A series of homologous binary distinctions between Western traditions of Christianity have also structured the relations between the great religions and the primitive. Thus the relation Protestant/Catholic is analogous to the relations: Hebrew/pagan; religion/magic; interior will/ external enactment; belief/ritual and so forth (Fardon 1999, 87).

It was not uncommon for these binary schematizations to be expressed in a developmental perspective with more developed traditions being less dependent on material elements than less developed, read primitive, or immature traditions, which revolved around concrete worship practices, religious objects, and sacred sites. Indeed, from the perspective of a certain elite, strange ritual practices were regarded as remnants of a primitive past, existing solely among the "ignorant and superstitious classes of modern

2 According to Orsi, fear of religion as fanatic has been central to the "academic installation of religious studies" (Orsi 2003, 170). However, it has also found its way into various expressions of governance of religion, among others via (inter)religious education. 
Europe" and "among the lowest savages surviving in the remotest corners of the world" (Frazer 1993, 49).

One more related element to this hierarchical presentation of religion is that more cultivated, advanced, and developed religions were presumably oriented to a more transcendent and universal "God," whereas less cultivated, less advanced, and underdeveloped religions remained oriented to a more tribal or particular God, manifested, and presented in the material world. The "ideal" image was that of an invisible, unrepresentable, and ineffable God who resists human control and containment. Religions that envisioned the relation with the divine as mediated by means of concrete, palpable material were devalued, and notions such as incarnated or embodied meaning and presentia realis became suspicious. It became associated not only with irrational magic but also with idolatry.

One of the consequences of this disdain for material and ritual practices is that religious scholars (and interreligious educators tend to follow this lead) focus primarily on written documents when they understand strange traditions. If material and ritual practices are associated with popular culture and perhaps even religion of the simple minded, texts give access to traditions' lasting ideas, beliefs, and insights as produced by the elite. The idea is moreover that written documents can be subjected to various hermeneutical analyses that enable the disclosure of meaning and truth even across traditions. Of course, religions that do not have written texts are often ignored. The disregard of non-textual wisdom traditions is significant, if we take into account that "the vast majority of religious expression throughout history has been of a nonliterate nature, taking the form of speech, song, performance or iconography" (King 1999, 62).

\section{Concluding Reflections}

The above-developed reflections are no doubt too sketchy; however, they do provide some insights into the historiography of the category of religion and its normative distinction between good and bad religion/mature and immature faith and how this distinction has functioned (and continues to function) to normatively categorize and study people and their traditions. To showcase just how prevalent (and problematic) this understanding of religion is even in interreligious education, the goal of which is to enhance interreligious literacy, I have examined Ricoeur's philosophy of religion.

As I explained in the introduction to this article, Ricoeur is one of the prominent conversation partners of many educators in their effort to think through the hermeneutical challenges of interreligious learning. For a long 
time, I have followed this lead. As I explained in the second part of this article, it has been my ascertainment that the reception of Ricoeur's philosophy of religion results in situations of testimonial and hermeneutical injustice, which are all but beneficial for the learning process of my students.

Of course, I can imagine that some readers will object by saying that Ricoeur's philosophy of religion is far more nuanced that the binaries evoked just now and that he would never subscribe to this radical way of opposing immature religion to more evolved and mature expressions of religiosity. Some might object by saying that the fault is on my side and that I do not explain properly Ricoeur's interreligious hermeneutics or that my students do not understand his thinking. All of this may be true, but it also remains true that Ricoeur is a heir of a modern understanding of religion and its normative distinction between mature and immature faith. One ought only to recall the textual focus of his linguistic hospitality; his distrust of ritualized aspects of religion; the way he distinguishes between the illimited and the limited; how he associates any effort to contain the ultimate with idolatry and violence to realize how his distinction between mature and immature faith is the product of modernity. Interreligious educators, who build on his philosophy and his projection of mature faith, ought to realize that they are continuing the history of marginalizing religious voices that do not fit a particular historical understanding of religion, while simultaneously favoring the voices of those students whose religious identity coincides with the modern 'Protestant' ideal of religion as pious, interiorized, and privatized.

Drawing on the cases from my classroom, I want to foreground how this normative distinction between good and bad religion/mature and immature faith is problematic from a pedagogical perspective. First of all, it negatively affects those students whose credibility status is lowered because their understanding of religion revolves, to use Orsi's term, around presence rather than absence and who are misrecognized in their capacity of producing knowledge that is worthy of consideration. It is not uncommon that students, who are faced with this sort of misrecognition in a systemic way, withdraw from contributing to the conversation and become silent. The situation of testimonial injustice, moreover, reinforces hermeneutical injustice. (Fricker 2017, 144-159). In the end, those who are marginalized do not participate in defining what is meaningful in a classroom (or society at large) (May 2013, 94-112). Being pushed to the defense, they are unable to critically challenge the normative (Ricoeurian) framework of the classroom.

Testimonial injustice is, however, also a problem for those students who cut themselves off from important insights and basically limit their own potential 
to learn more and understand better. Ricoeur's hermeneutical framework seems to strengthen the self-righteousness of my liberal students. They boast themselves about having already reached the learning target: open-minded mature faith. At no time are they really challenged to leave their comfort zone and critically reflect on the prejudiced nature of their own position.

My concern is that interreligious educators who profile themselves as cultural brokers enabling interreligious understanding will uncritically tap into the normative distinction between good and bad religion. While projecting a vision of interfaith solidarity and increased social cohesion, they actually risk contributing to the marginalization of those students who do not find themselves on the right side of the line. The end result is that situations of testimonial and hermeneutical injustice continue to exist. Interreligious educators have to ask how their interfaith pedagogy and interreligious hermeneutics contribute to the perseverance of the normative distinction between good and bad religion, which in the final analysis reproduces inequalities and exclusion.

\section{References}

Ulrick Beck. 2014.“The Two Faces of Religion.” In Pioneer in Cosmopolitan Sociology and Risk Society, edited by Ulrichs Beck, pp. 128-141. London/Dordrecht: Springer Science \& Business Media.

Bell, Catherine. 2007. Teaching Ritual. Oxford: Oxford University Press.

Berger, Peter. 2014. The Many Altars of Modernity: Toward a Paradigm for Religion in a Pluralist Age. New York: Walter DeGruyter.

Blackburn, Anne. 2012. "The Text and the World.” In The Cambridge Companion to Religious Studies, edited by Robert A. Orsi, pp.151-167. Cambridge: Cambridge University Press.

Changeux, Jean-Pierre and Ricoeur, Paul. 2002. What Makes us Think? A Neuroscientist and a Philosopher Argue about Ethics, Human Nature, and the Brain. Princeton: Princeton University.

De Dijn, Herman. 1999. "Values and Incarnation." In Incarnation, edited by Marco M. Olivetti, pp. 371-379. Padova, CEDAM.

Dieleman, Susan. 2012. "An Interview with Miranda Fricker." Social Epistemology: a Journal of Knowledge: Culture and Policy 26; online access 30.06.2018.

Daggers, Jenny. 2013. Postcolonial theology of religions: particularity and pluralism in world Christianity. New York: Routledge

Douglas, Mary. 2013. Purity and Danger: An Analysis of Concepts of Pollution and Taboo. London: Routledge.

Fabretti, Valeria. 2013. "Learning from Religions: Post-secular Schools and the Challenge of Pluralism," Italian Journal of Sociology of Education 5: 46-66.

Fardon, Richard. 1999. Mary Douglas: An Intellectual Biography. London: Routledge. 


\section{Journal of Nationalism, Memory \& Language Politics 13(2)}

Fitzgerald, Timothy. 2011. Religion and Politics of International Relations: The Modern Myth, London/New York: Bloomsbury.

Foody, Kathleen. 2016. “Pedagogical Projects: Teaching Liberal Religion After 9/11.” The Muslim World 106: 719-739.

Ford, David. 2006. "An Interfaith Wisdom: Scriptural Reasoning Between Jews, Christians and Muslims." Modern Theology 22: 345-66.

Frazer, James G. 1993. The Golden Bough: A Theory of Magic and Religions. Ware: Wordsworth Edition.

Fricker, Miranda. 2007. Epistemic injustice: Power and the Ethics of Knowing. New York, Oxford University Press.

Fricker, Miranda. 2017. “Epistemic Injustice and The Preservation of Ignorance.” In The Epistemic Dimensions of Ignorance, edited by Rik Peels and Martijn Blaauw, pp.144-159. Cambridge: Cambridge University Press.

Garcia, Leovino. 2008. "On Paul Ricœur and the Translation-Interpretation of Cultures." Thesis Eleven 94: 72-87.

Huskey, Rebecca. 2009. Paul Ricoeur on Hope: Expecting the Good. New York: Lang Publishing.

Jervolino, Domenico. 2006. "Pour une philosophie de la traduction." Revue de métaphysique et de morale 2: 229-238.

Kearney, Richard. 2011. Anatheism: Returning to God after God, New York: Columbia University Press.

King, Richard. 1999. Orientalism and Religion: Postcolonial Theory, India and the 'Mystic East'. London/New York: Routledge.

Matern, Jens. 2008. Zwischen kultureller Symbolik und allgemeiner Wahrheit. Nordhausen: Traugott Bautz.

May, Vivian M. 2013. "Speaking into the Void?, Intersectionality, critiques and Epistemic Backlash.” Hypatia 29: 94-112.

McCutcheon, Russel T. 2005, ${ }^{2} 2008$. Religion and the Domestication of Dissent. Or How to Live in a Less than Perfect Nation. London: Equinox.

Meyer, Birgit and Houtman, Dick. 2012. Things: Religions and the Question of Materiality. New York: Fordham University Press.

Moyaert, Marianne. 2019. "Wrestling with Scripture and Avoiding Violence in a Multireligious Classroom." In Scripture and Violence, edited by Julia Snyder \& Daniel Weiss. London: Routledge. Forthcoming.

Moyaert, Marianne. 2017a. "Interreligious Literacy and Scriptural Reasoning: Some hermeneutical, Anthropological, Pedagogical and Experiential Reflections." Studies in Interreligious Dialogue 27: 3-26.

Moyaert, Marianne. 2014. In Response to the Religious Other: Ricoeur and the Fragility of Interreligious Encounters. London: Lexington.

Moyaert, Marianne. 2009. "A Babelish World (Genesis 11:1-9) and Its Challenge to CulturalLinguistic Theory." Horizons: The Journal of the College Theology Society 36: 215-234. 


\section{Marianne Moyaert. Interreligious Learning, Ricoeur, and the Problem of Testimonial and Hermeneutical Injustice}

Nongbri, Brent. 2013. Before Religion: a History of a Modern Concept. New Haven/London: Yale University Pres.

Orsi, Robert. 2016. History and Presence. Cambridge, MA: Harvard University Press.

Patel, Eboo. 2016. Interfaith Leadership: a Primer. Boston: Beacon Press.

Pollefeyt, Didier and Bouwens, Jan. 2014. Identity in Dialogue: Assessing and enhancing Catholic school identity. Research methodology and research results in Catholic schools in Victoria, Australia. Vienna: Lit.

Pollefeyt, Didier and Bouwens, Jan. 2010. "Framing the Identity of Catholic Schools: Empirical Methodology for Quantitative Research on the Catholic Identity of Educational Institutions." International studies in Catholic Education 2: 193-211.

Puett, Tifanny. 2014. The Political Discourse of Religious Pluralism: World Religions Textbooks, Liberalism, and Civic Identities. Phd, Waterloo, Ontario.

Ricoeur, Paul. 2010. "Religious Belief: The Difficult Path of the Religious." In A Passion for the Possible: Thinking with Paul Ricoeur, edited by Brian Treanor and Henry Venema, pp. 27-41. New York: Fordham University Press, 2010.

Ricoeur, Paul. 2006. On Translation. Translated by Richard Kearney (Thinking in Action), London: Routledge.

Ricoeur, Paul. 1999. "Religion and Symbolic Violence." Contagion: Journal of Violence, Mimesis, and Culture 6: 1-11.

Ricoeur, Paul. 1999. Figuring the Sacred: Religion, Narrative, and Imagination, edited by Mark Wallace. Minneapolis: Fortress Press.

Ricoeur, Paul. 1977. “Hermeneutique de l'idée de la Révélation.” In La Révélation, edited by Paul Ricoeur, 15-54. Bruxelles: Facultés Universitaires St Louis.

Ricoeur, Paul. 1974. The Conflict of Interpretation. Evanston: Northwestern University Press, 440-467.

Shakman Hurd, Elizabeth. 2015. Beyond Religious Freedom: The New Global Politics of Religion, Princeton, NJ: Princeton University Press.

Staudigl, Michael. 2016. "On Seizing the Source: Toward a Phenomenology of Religious Violence." International Journal of Philosophical Studies 24: 744-782.

Taylor, James and Kearney, Richard. Ed. 2014. Hosting the Stranger between Religions, London: Continuum.

Van Herck, Walter. 2007. "A Friend of Demea? The Meaning and Importance of Piety." In, D.Z. Phillips' Contemplative Philosophy of Religion, edited by Andy Sanders, pp. 125-138. Hampshire: Ashgate. 